\title{
Improving Energy Efficiency in New Trawlers Fishing Gear in Mediterranean Sea
}

\author{
Agustín Mayans Fernández ${ }^{1}$, Ignacio J. Martínez Soler ${ }^{1}$, Antonio V. Martínez Sanz ${ }^{2}$, Vicente Colomer Romero ${ }^{2}$ \\ 1 Simrad Spain S.L.U, Polígono Partida Torres, 38, Villajoyosa, Alicante, 03570, Spain \\ 2 Institute of Design and Manufacturing, Universitat Politècnica de València, Valencia, 46022, Spain
}

\begin{abstract}
The objective of this work is to show the benefits of a new eco-systemic fishing gear installed in three bottom trawlers after one year using it. The study has been based on fuel consumption reduction for the three vessels and the catch in two of them. The new system minimizes the impact of the fishing gear on the seabed, with a reduction on the tow resistance. This generates significant fuel savings that improves the economical result of the fishery, helping the ship owners in the return of investment first, then in the future viability of the operation. Apart of the evident savings due to the fuel consumption reduction, in the long term, the ship owner will notice also savings on maintenance, both because the winches are towing with less tension (longer life for warps, brakes and hydraulic system) and the engine is running at low rpm's (longer life of the engine and between breakdowns). The new fishing gear does not require any modification on the way that the fisherman is working, only replacing and/or modifying some parts or components of the fishing gear. The implementation is easy and the adjustments required could be done in a couple of days.
\end{abstract}

Key words: Mediterranean trawlers, fishing gear, flying bottom trawl doors, energy efficiency, electronics systems.

\section{Introduction}

The Financial Instrument for Fisheries Guidance rules did not permit the grant of the modernization of fishing gear for community vessels.

The current rules for the European Fisheries Fund 2007-2013, the EC Regulations 1198/2006 (in its Article 21 and 25) and the EC 498/2007 (Article 6) allow this type of action.

Priority Axis 1 allows for the financing of investments to more selective fishing gear provided that the new gear is more selective and meets recognized standards and environmental practices, more stringent than existing regulatory obligations under community law.

This project is part of the selection criteria defined in this Measure.

Corresponding author: Agustín Mayans Fernández, Ph.D., research fields: fishing gear technology, subsea robotics and acoustics. E-mail: agustin.mayans@simrad.com.

\section{Methodology}

2.1 Vessels from Santa Pola Harbour "Magú” and "Rosqui"

In the vessels "Magú" and "Rosqui", the fuel consumption data have been collected from the fuel station invoices of the last two years. From these invoices, we have extracted the amount of liters. Having the price of the fuel from the fuel station records, we have calculated the cost of the fuel each time the tank was filled.

The catch data have been collected from the daily auction report in a weekly report. We have noted not only the total amount of the sale, but also the main species accounted separately in order to compare the catch volumes before and after the implementation of the new fishing gear.

With the catch volume and the money collected at the auction, we have noted the price evolution of the catches.

The data collection in "Magú” and "Rosqui” starts 
in November 2011 (period 1), where the vessels were equipped with traditional bottom trawl doors (Thyboron T-11 and Poly-Ice, El Cazador models, respectively) and OTB4 trawl net

The new fishing gear was installed in November 2013 (period 2). Then the traditional trawl doors were replaced by flying bottom trawl doors Thyboron $\mathrm{T}-15 \mathrm{VF}$. The net was replaced by a similar design OTB4 but increasing the mesh size and decreasing the netting in all upper and side panels.

A selective rectangular panel, build with Dyneema Ultra Cross knotless squared $40 \mathrm{~mm}$ (3mm netting), was installed in top of the extension piece to increase the selectivity of the fishing gear.

\subsection{Vessel from Mahón “Nuevo Joven Josefina”}

For the third vessel, "Nuevo Joven Josefina”, the data have been collected onboard by the skipper and only reflects the fuel consumption over the last three years: one year with the previous system and two years with the new fishing gear.

The "Nuevo Joven Josefina" installed the new fishing gear under the project Portes [1], commanded by the IEO (Centre Oceanogràfic de Balears) where Simrad Spain was collaborating. In the project publication, more detailed information can be founded (catches, trawl measurements, fuel consumption, etc.) but only for the period of the project.

Trawl telemetry was collected in the three cases in order to check that the size of the new fishing gear was identical. The new flying bottom trawl doors' spread is always bigger due to the fact that the length between the trawl door and the wings of the net increases due to the length of the chain and the compensation warp.

\section{Results}

\subsection{Catches Price Evolution ("Magú” and "Rosqui”)}

From the auction bills received from both vessels,

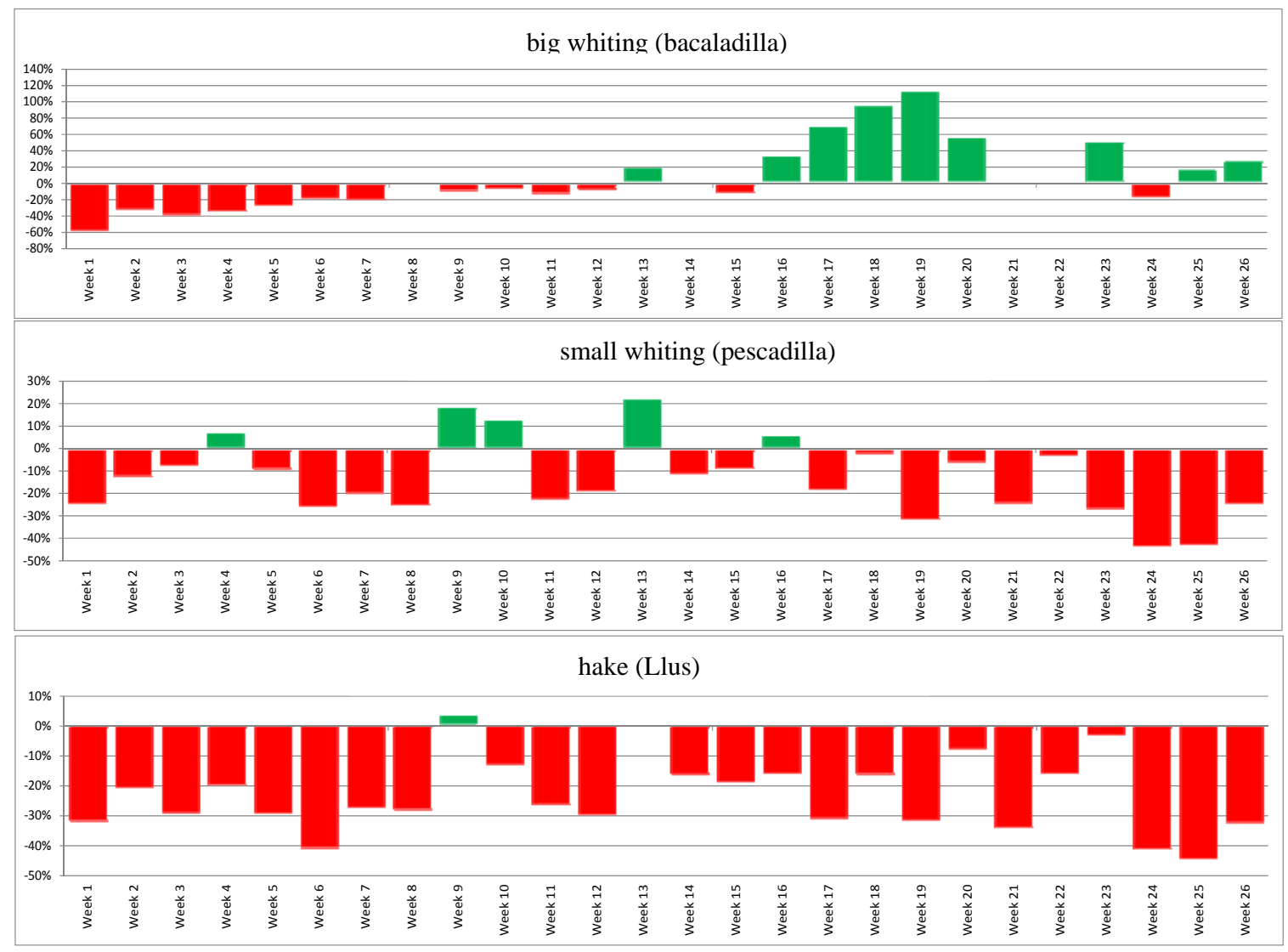

Fig. 1 Differential in auction prices for hake and whiting from periods 1 and 2. 
we have compared the average of price paid in the same week of period 1 and period 2. In the following graphs, it reflected the evolution in the three main species: big whiting (bacaladilla), small whiting (pescadilla) and hake (Llus).

The green bars show an increase in the price paid, the red that the general trend was downwards.

In Santa Pola, the price of the catches decreased significantly during period 2, compared to period 1 .

Regarding catch volume, it was better in period 2, but the reason is not an increase of fishing effort due to the new fishing gear. The amount of hake was just bigger but in the rest of species, we have noticed similar catch level or even a light decrease.

We can see how the excess of catch volume affects to the market price downwards. This could be a good indicator for the fisherman that shows how a modulation of the catche, as per the market demand, will be more profitable than just increase the catch over the demand level. Maybe a good idea would be to ask the fishing.

Comparing period 2 with period 1, the increase in catch volume for "Magú" was 19.95\% (from 93.859 $\mathrm{kg}$ to $112.584 \mathrm{~kg}$ ) but the turnover dropped $4.34 \%$ (from 466.323€ to 446.084€) which means $20.239 €$ less than last period.

In the case of "Rosqui", the catches in period 2 increased 6.13\% from period 1 (from $81.688 \mathrm{~kg}$ to $86.695 \mathrm{~kg}$ ) but the turnover dropped $10.16 \%$ (from $418.795 €$ to $376.262 €$ ) which means $42.533 €$ less than last period.

\subsection{Fuel Consumption ("Magú” and "Rosqui”)}

Since the new fishing gear was installed, both vessels experienced a drop in the fuel consumption due to the resistance reduction, thus less towing force to use.

In the case of "Magú", the fuel consumption average in period 1 was 2.201 liter/day. In period 2, it was reduced to 1.735 liter/day (21.17\% less). The yearly cost of the fuel was $336.868 €$ in period 1 against 222.059€ in period 2. A reduction of $114.809 €$ which means a $34.08 \%$. The actual reduction in total fuel consumption was 154.400 liters (30.90\% from 499.700 liters in period 1 to 345.300 liters in period 2).

In the case of "Rosqui", the fuel consumption average in period 1 was 1.378 liter/day. In period 2, it was reduced to 1.250 liter/day (9.29\% less). The yearly cost of the fuel was $207.924 €$ in period 1 against $160.000 €$ in period 2. A reduction of $47.924 €$ which means a $23.05 \%$. The actual reduction in total fuel consumption was 59.900 liters (19.41\% from 308.600 liters in period 1 to 248.700 liters in period 2).

Regarding $\mathrm{CO}_{2}$ emissions, using the ratio of $2.66 \mathrm{~kg}$ per liter of fuel ${ }^{1}$, the total reduction from these two vessels was $570.038 \mathrm{~kg}$.

We must note that the fishing grounds of "Magú" are most of the time in deep waters, "Rosqui" operates always in shallow waters. The towing speed in deep waters was reduced by "Magú" and that is why the reduction in fuel consumption is so big. Due to the target species in shallow waters, "Rosqui" did not reduce the towing speed, resulting in a lower reduction.

\subsection{Fuel Consumption ("Nuevo Joven Josefina”)}

During the project "Portes", the reduction in fuel consumption observed in this vessel was 14\% in deep waters and $4 \%$ in shallow waters. Even this vessel operates most of the time in deep water, during the project both areas were tested.

This matches with the results of "Magú" and "Rosqui", where the difference between fuel savings was $30.90 \%$ and $19.41 \%$, respectively.

With the data collected by the skipper, we can see a fuel consumption average of 621.7 liter/day, with the traditional fishing gear. With the new fishing gear, this figure dropped to 476.3 liter/day which means a $23.31 \%$ of reduction.

\footnotetext{
${ }^{1}$ Source: Instituto para la diversificación y el ahorro IDAE (www.idae.es).
} 

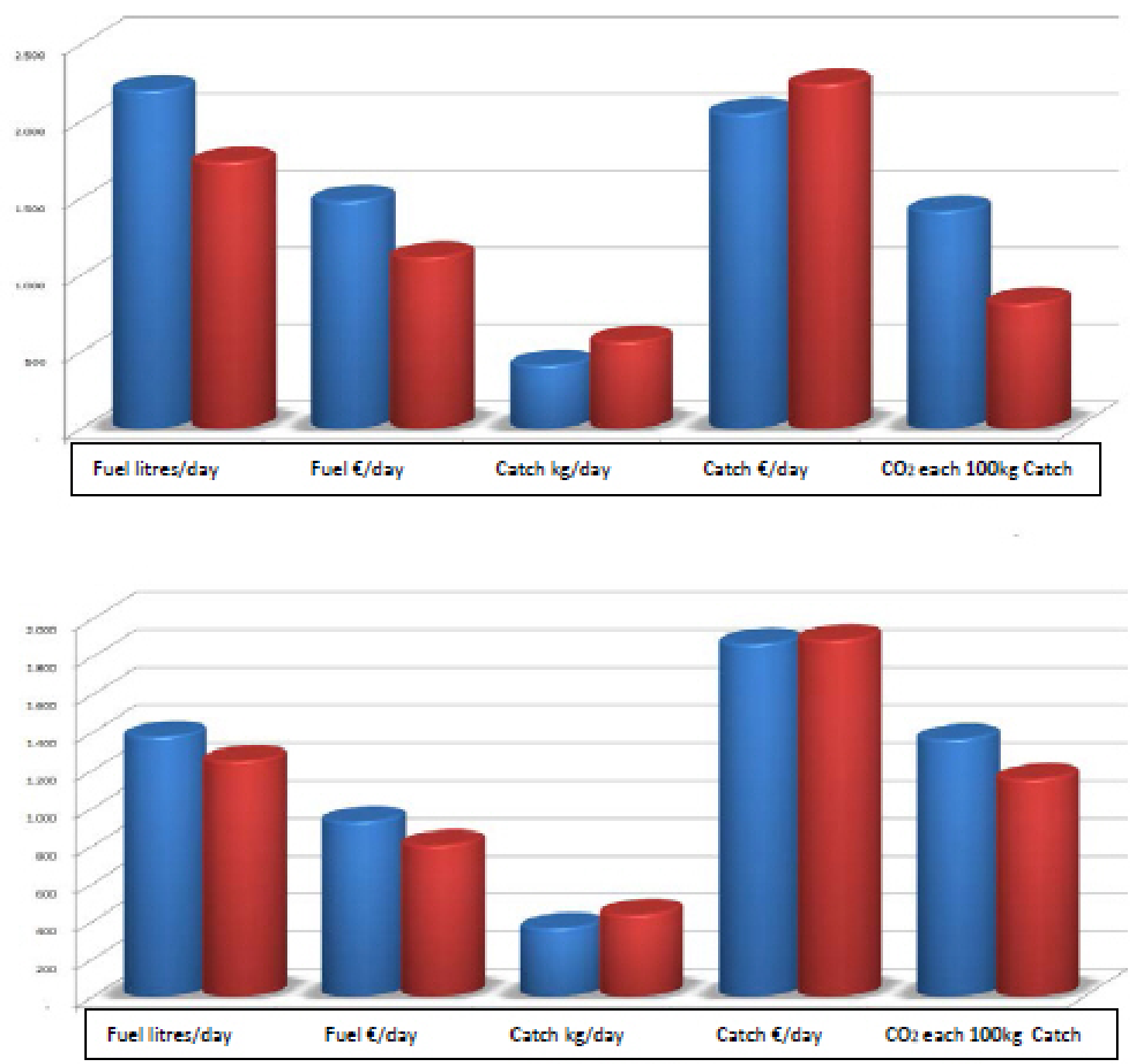

G Traditional a New

Fig. 2 Statistics from Magú (up) and Rosqui (down).

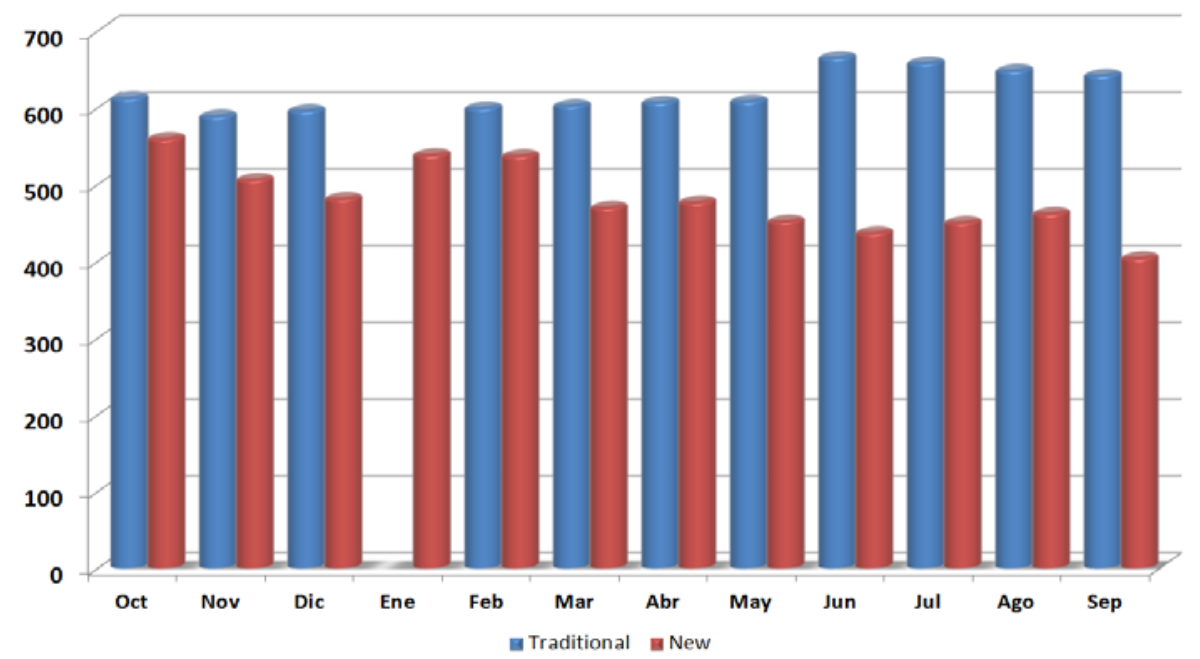

Fig. 3 Average fuel consumption comparison (in litter/day) between traditional gear and the new gear installed in Nuevo Jove Josefina. 
Fig. 4 Track of a bottom trawl door in the bottom.

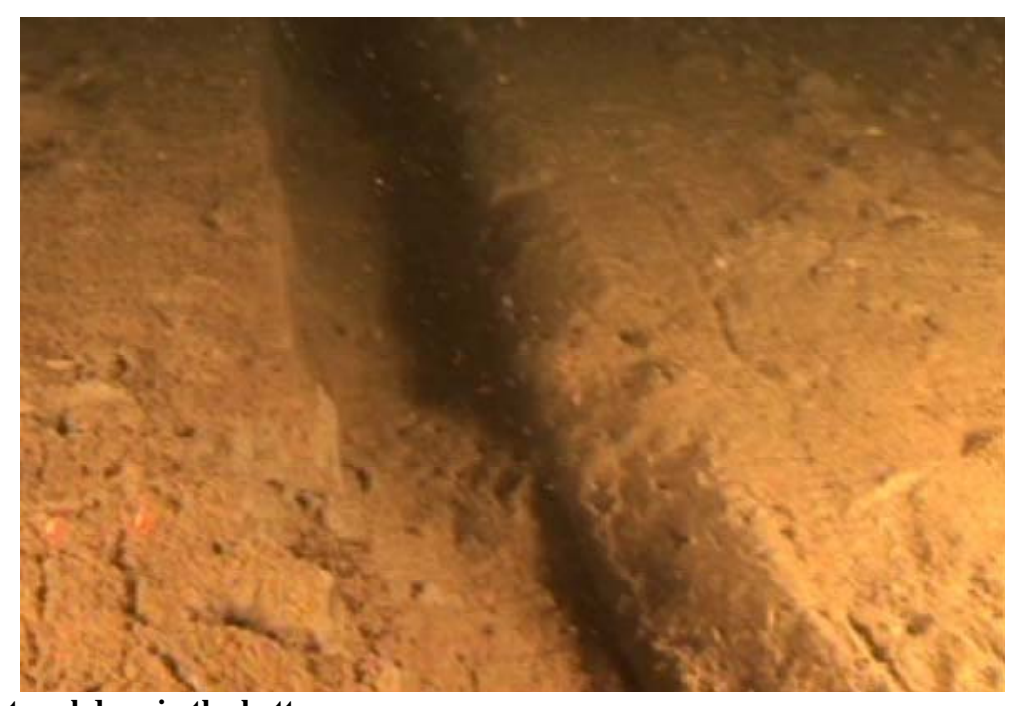

Source: Dr. Josep María Gili (Spanish National Research Council).

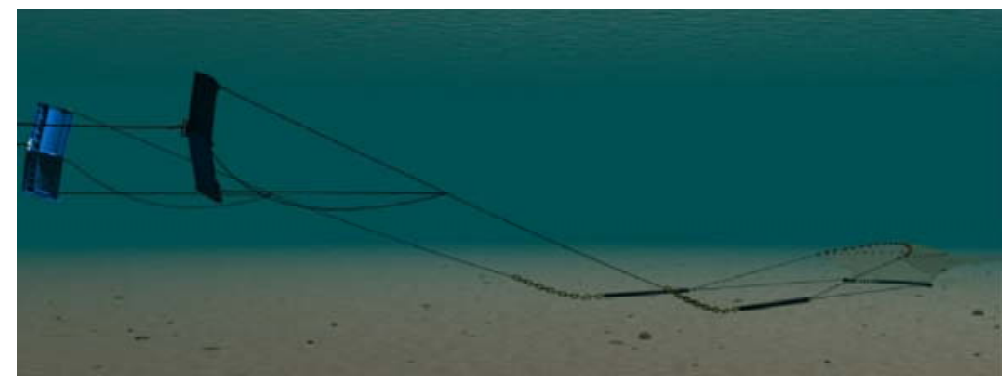

Fig. 5 New fishing gear arrangement with flying bottom trawl doors.

From the above graph, we can see how the skipper has been improving with time, being the differential much bigger as he was getting experience with the new fishing gear to tune it up.

If we compare the last month of each period (September 2009 against September 2012) the difference is from 642.3 liter/day to 404.4 liter/day. This means a final reduction of $37.04 \%$.

\section{Conclusions}

There are three evident impacts observed after the installation of the new fishing gear:

\subsection{Physical Impact over the Seafloor}

The bottom trawl doors works with a typical angle of attack of $40^{\circ}$ being the keel semi buried on the seafloor.

If we calculate the impact area of each trawl door, based on the keel length, in the case of "Magú", the track would be 1.34 meters wide. In the case of "Rosqui", it would be 1.22 meters.

With the flying bottom trawl doors, this impact is reduced as the trawl door works off the bottom. Only a compensation chain load is installed to keep the fishing gear on the bottom, but as the chain is aligned with the sweep line, it keeps the same angle.

\section{2 $\mathrm{CO}_{2}$ Emisions}

As the fuel consumption is reduced, the $\mathrm{CO}_{2}$ emissions are reduced proportionally as per $266 \mathrm{~kg}$ per liter ${ }^{2}$.

\subsection{Economic Improvement of the Operation}

The current economic situation of many ship owners is critical now. Fuel cost is around $45 \%$ of their expenses and a reduction in this amount will

\footnotetext{
${ }^{2}$ Source: Instituto para la diversificación y el ahorro IDAE (www.idae.es).
} 
have a very positive impact in the final result of the vessel.

The return of investment is very fast. Eight months for the investment in "Magú" and 14 months for the investment in "Rosqui".

\section{Acknowledgments}

Joaquín González, shipowner of the fishing vessels “Magú” and "Rosqui”;

Gaspar Melcior, shipowner of the fishing vessel "Nuevo Joven Josefina";

Manuel Agulló Sóler and Angel Luchoro, from the “Cofradía de Pescadores de Santa Pola”;

Dr. Josep María Gili, Researcher in C.S.I.C.

\section{References}

[1] Frederic, V. V., Carmen, R. A., and José, E. R. M. 2010
"Improvement of the Efficiency, Sustainability and Benefit of the Catalan Trawl Fishing Fleet.” E-Fishing.

[2] Enric, M., Agustín, M., Antoni, M. G., Miquel, M., Ignacio, S., Francesc O. Eva M. V. María V. Gaspar M. Santiago S. Gabriel, M., and Joan M. "New system for reducing the impact of fishing of bottom trawling on the Spanish coasts of the Mediterranean" http://www.ba.ieo.es/investigacion/informes-tecnicos/947 -informe-final-del-proyecto-portes, December 2011.

[3] Martínez Sanz, A. V., Soler Martínez, I. J., Salom Llorach, S., Colomer Romero, V., and Mayans Fernández, A. 2011. "Improving Energy Efficiency in New Trawlers Fishing Gear in Alicante.” Presented at the 4th International Congress of Energy and Environment Engineering and Management (CIIEM 2011). Mérida, Spain.

[4] Martínez Sanz, A. V., Soler Martínez, I. J., Colomer Romero, V., and Mayans Fernández, A. 2012. "New Technologies of Energetic Efficiency Applied to Mediterranean Trawl Fishery." Presented at the 16th International Congress on Project Engineering. Valencia, Spain. 